\title{
The first activation study of a bacterial carbonic anhydrase (CA). The thermostable $\alpha$-CA from Sulfurihydrogenibium yellowstonense YO3AOP1 is highly activated by amino acids and amines
}

\author{
Daniela Vullo $^{\mathrm{a}}$, Viviana De Luca ${ }^{\mathrm{b}}$, Andrea Scozzafava ${ }^{\mathrm{a}}$, Vincenzo Carginale ${ }^{\mathrm{b}}$, Mosè Rossi ${ }^{\mathrm{b}, \mathrm{c}}$, \\ Claudiu T. Supuran ${ }^{\mathrm{a}, \mathrm{d}, *}$, Clemente Capasso ${ }^{\mathrm{b}, *}$ \\ ${ }^{a}$ Università degli Studi di Firenze, Polo Scientifico, Laboratorio di Chimica Bioinorganica, Rm. 188, Via della Lastruccia 3, 50019 Sesto Fiorentino, Florence, Italy \\ ${ }^{\mathrm{b}}$ Istituto di Biochimica delle Proteine - CNR, Via P. Castellino 111, 80131 Napoli, Italy \\ ${ }^{\mathrm{c}}$ Centro di Ricerca Interdipartimentale sui Biomateriali, Univ. Federico II, P-le V. Tecchio 80, 80125 Napoli, Italy \\ ${ }^{\mathrm{d}}$ Università degli Studi di Firenze, Polo Scientifico, Dipartimento di Scienze Farmaceutiche, Via Ugo Schiff 6, 50019 Sesto Fiorentino, Florence, Italy
}

\section{A R T I C L E I N F O}

\section{Article history:}

Received 3 August 2012

Revised 21 August 2012

Accepted 23 August 2012

Available online 30 August 2012

\section{Keywords:}

Carbonic anhydrase

Bacterial enzyme

Activator

Amino acid

Amine

$\mathrm{CO}_{2}$ capture

\begin{abstract}
A B S T R A C T
The $\alpha$-carbonic anhydrase (CA, EC 4.2.1.1) from the newly discovered thermophilic bacterium Sulfurihydrogenibium yellowstonense YO3AOP1 (SspCA) was investigated for its activation with a series of amino acids and amines. D-His, L-Phe, L-Tyr, L- and D-Trp were the most effective SspCA activators, with activation constants in the range of $1-12 \mathrm{nM}$, whereas L-His, L/D-DOPA, D-Tyr, and several biogenic amines/catecholamines were slightly less effective activators $\left(K_{\mathrm{A}}\right.$ in the range of $\left.37 \mathrm{nM}-0.97 \mu \mathrm{M}\right)$. The least effective SspCA activator was D-Phe $\left(K_{\mathrm{A}}\right.$ of $\left.5.13 \mu \mathrm{M}\right)$. The thermal stability, robustness and very high catalytic activity of SspCA make this enzyme an ideal candidate for biomimetic $\mathrm{CO}_{2}$ capture processes.
\end{abstract}

(c) 2012 Elsevier Ltd. All rights reserved.
The increase in the atmospheric concentration of gases with greenhouse effect, including the elevation of carbon dioxide $\left(\mathrm{CO}_{2}\right)$ caused by the anthropogenic activities, represents one of the main factors of high environmental stress, being considered as one of the main causes of climate change. ${ }^{1}$ The production of eco-compatible fuels and the reduction of $\mathrm{CO}_{2}$ emissions in the atmosphere represent challenges of basic and applied research, from both an environmental and economic viewpoint. A number of $\mathrm{CO}_{2}$ sequestration methods have been proposed in order to capture and concentrate $\mathrm{CO}_{2}$ from combustion gases, for its transit and storage. ${ }^{2}$ One of them is based on the chemical absorption of $\mathrm{CO}_{2}$ by alkanolamines and its subsequent stripping with steam, to produce a gas that can be transported to a geologic or marine sequestration site. ${ }^{3,4}$ However, this process is expensive and not convenient in all situations. The sequestration of $\mathrm{CO}_{2}$ as a salt is also interesting since the carbonate minerals represent the largest reserve of $\mathrm{CO}_{2}$ on earth. ${ }^{4}$ However, the latest years have seen the development of a new, interesting approach, the $\mathrm{CO}_{2}$ capture, which represents a biomimetic method. ${ }^{5}$ This approach uses

\footnotetext{
* Corresponding authors. Tel.: +39 055 4573005; fax: +39 0554573385 (C.T.S.); tel.: +39081 6132559; fax: +390816132712 (C.C.).

E-mail addresses: claudiu.supuran@unifi.it (C.T. Supuran), c.capasso@ibp.cnr.it (C. Capasso).
}

microorganisms capable of fixing $\mathrm{CO}_{2}$ through metabolic pathways or via the use of an enzyme, namely carbonic anhydrase (CA, EC 4.2.1.1)..$^{5} \mathrm{CA}$ is able to convert $\mathrm{CO}_{2}$ into bicarbonate and protons with high efficacy, is selective for this substrate and represents a great potential in the development of eco-friendly and cost-effective processes for $\mathrm{CO}_{2}$ capture. ${ }^{5}$

CAs are ubiquitous metallo-enzymes present in all life kingdoms. They are divided into five evolutionary distinct classes, the $\alpha, \beta$ and $\gamma$, as well as the recently discovered classes, $\delta$ and $\zeta$ classes (in marine diatoms). ${ }^{6-10}$ The human (h) isoforms CA II (hCA II) and IX (hCA IX), two enzymes highly investigated to date, are catalytically the fastest members of the $\alpha$-class CA family, and among the fastest enzymes known. ${ }^{11}$ Recently, our group described the biochemical properties of an 'extremo- $\alpha$-CA' denominated SspCA, an $\alpha$-class CA from the bacterium Sulfurihydrogenibium yellowstonense YO3AOP $1 .^{12}$ SspCA showed biochemical properties never observed for a mesophilic enzyme, being endowed with high thermostability and with unaltered residual activity after prolonged exposure to heat up to $100{ }^{\circ} \mathrm{C}^{12}$ Besides, SspCA showed a $k_{\text {cat }}$ value of $9.35 \times 10^{5} \mathrm{~s}^{-1}$ denoting that the 'extremo $\alpha$-CA' was one of the most effective CAs known to date. ${ }^{12,13}$

Recently, it was reported that a multitude of physiologically important compounds, such as biogenic amines (histamine, serotonin, and catecholamines), amino acids, oligopeptides, or small 
proteins, among others, work as efficient CA activators (CAAs). ${ }^{14}$ These molecules have the potential to be used in the treatment of Alzheimer's disease, in aging, as well as for achieving spatial learning and memory therapy. ${ }^{15-18}$ By means of electronic spectroscopy, X-ray crystallography and kinetic measurements, it has been proved that CAAs bind within the enzyme active cavity at a site distinct of the inhibitor or substrate binding-sites, participating thereafter in the rate-determining step of the catalytic cycle, that is, the proton transfer reaction between the active site and the environment. ${ }^{15-18}$

Here we report an activation study of SspCA with a range of amino acids and amines previously investigated as activators of mammalian and fungal CAs. ${ }^{19,20}$ It should be stressed that no bacterial CAs were investigated to date for interaction with activators, although many inhibition studies are available in the literature. $^{19,20}$

L-/D-Amino acids and amines of types 1-19 investigated as SspCA activators are commercially available and were investigated earlier as activators of all human CA isoforms (from hCA I to hCA $\mathrm{XV}){ }^{15-18,21}$
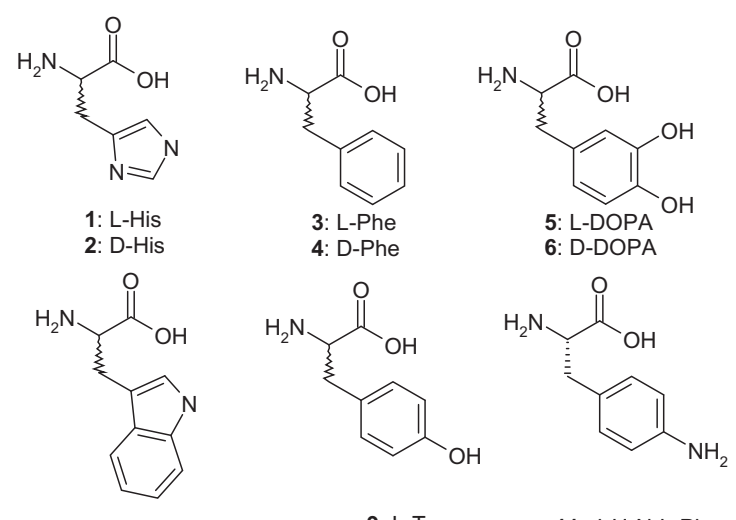

$$
\begin{aligned}
& \text { 7: L-Trp } \\
& \text { 8: D-Trp }
\end{aligned}
$$

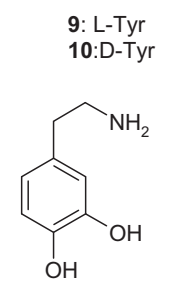

13

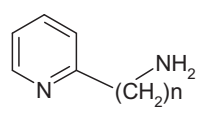

15: $\mathrm{n}=1$ 16: $n=2$

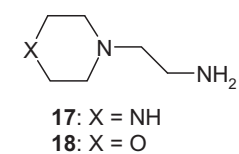

18: $X=O$

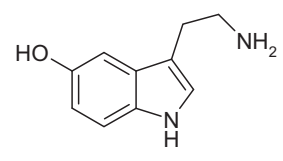

14

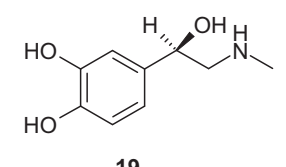

19
Kinetic experiments for the physiological reaction (carbon dioxide hydration to bicarbonate and a proton) (Table 1 ) showed that as for hCA I and II, ${ }^{73-15}$ activators of the amino acid or amine type, enhance $k_{\text {cat }}$ of the enzyme, with no effect on $K_{\mathrm{M}}$. Indeed, as observed from data of Table 1, L- or D-Phe (compounds 3 and 4 ) at a concentration of $10 \mu \mathrm{M}$, produced a notable enhancement of $k_{\text {cat }}$ for all investigated isoforms, that is, hCA I, hCA II and SspCA. Thus, for hCA I, this parameter for the pure enzyme is of $2.0 \times 10^{5} \mathrm{~s}^{-1}, 10$ whereas in the presence of activators 3 and $\mathbf{4}$ at a concentration of $10 \mu \mathrm{M}$, it becomes of $2.3-19.8 \times 10^{5} \mathrm{~s}^{-1}$. For hCA II, the enhancement of $k_{\text {cat }}$ from the value of the pure enzyme $\left(1.4 \times 10^{6} \mathrm{~s}^{-1}\right)$ is in the range of 5.2-5.7 $\times 10^{6} \mathrm{~s}^{-1}$ in the presence of the two activators. For SspCA in the presence of the moderate activator D-Phe, an enhancement of 4.4 times of $k_{\text {cat }}$ was observed, whereas the very
Table 1

Kinetic paramaters for the activation of hCA isozymes I, II, as well as the bacterial one

\begin{tabular}{|c|c|c|c|c|c|}
\hline \multirow[t]{2}{*}{ Isozyme } & \multirow[t]{2}{*}{$k_{\text {cat }}{ }^{\mathrm{a}}\left(\mathrm{s}^{-1}\right)$} & \multirow[t]{2}{*}{$\left(k_{\text {cat }}\right) \mathrm{L}-\mathrm{Phe}^{\mathrm{b}}\left(\mathrm{s}^{-1}\right)$} & \multirow[t]{2}{*}{$\left(k_{\text {cat }}\right)_{\mathrm{D}-\mathrm{Phe}} \mathrm{b}^{\mathrm{b}}\left(\mathrm{s}^{-1}\right)$} & \multicolumn{2}{|c|}{$K_{\mathrm{A}}^{\mathrm{c}}(\mu \mathrm{M})$} \\
\hline & & & & L-Phe & D-Phe \\
\hline hCA I ${ }^{\mathrm{d}}$ & $2.0 \times 10^{5}$ & $19.8 \times 10^{5}$ & $2.3 \times 10^{5}$ & 0.07 & 86 \\
\hline hCA II ${ }^{\mathrm{d}}$ & $1.4 \times 10^{6}$ & $5.7 \times 10^{6}$ & $5.2 \times 10^{6}$ & 0.013 & 0.035 \\
\hline SspCA & $9.35 \times 10^{5}$ & $1.4 \times 10^{7}$ & $4.1 \times 10^{6}$ & 0.008 & 5.13 \\
\hline
\end{tabular}
SspCA with L- and D-Phe, at $25{ }^{\circ} \mathrm{C}$ and $\mathrm{pH} 7.5$, for the $\mathrm{CO}_{2}$ hydration reaction ${ }^{21}$

a Observed catalytic rate without activator. $K_{\mathrm{M}}$ values in the presence and the absence of activators were the same for the various CA isozymes (data not shown). $K_{\mathrm{M}}$ for SspCA was $8.4 \mathrm{mM}$ in the absence or the presence of activators.

$\mathrm{b}$ Observed catalytic rate in the presence of $10 \mu \mathrm{M}$ activator.

c The activation constant $\left(K_{\mathrm{A}}\right)$ for each isozyme was obtained as described earlier, ${ }^{21}$ and represents the mean from at least three determinations by a stoppedflow, $\mathrm{CO}_{2}$ hydrase assay method. ${ }^{21}$ Standard errors were in the range of $5-10 \%$ of the reported values.

d Human recombinant isozymes.

effective activator L-Phe produced an enhancement of the $k_{\text {cat }}$ of almost 15 times, the highest ever observed with any CAA (Table 1 ). It may be thus observed that the two enantiomers of this amino acid show a very different behavior as activators of SspCA although both of them enhance the catalytic rate.

Detailed kinetic measurements (i.e., for determining $k_{\text {cat }}$ and $K_{\mathrm{M}}$ values) have been performed with all the investigated derivatives 1-19, but only values for $\mathrm{L}-/ \mathrm{D}-\mathrm{Phe}$ are reported in Table 1 , for the sake of simplicity, as the other derivatives behaved similarly with these two CAAs.

SspCA activation constants $\left(K_{\mathrm{A}} \mathrm{S}\right)$ for a series of structurally related amino acids and amines of types 1-19 are shown in Table 2. The activation constants for the ubiquitous isozymes hCA I and hCA II are also provided for comparison. Similarly with the inhibition constant $K_{\mathrm{I}}$, (for the enzyme inhibitors), ${ }^{19}$ the activation constant $K_{\mathrm{A}}$ measures the affinity of the activator for the enzyme. The lower this parameter, the stronger is the activator against the corresponding isoform. ${ }^{15-17,19}$ Compounds 1-19 were shown earlier to act as activators of the human isozymes hCA I to XIV. ${ }^{15-20}$ All of them possess protonatable moieties of the primary amine or heterocyclic amine type (or both of them), being thus able to participate in proton transfer processes leading to the generation of the nucleophilic species of the enzyme, with the hydroxide anion coordinated to the active site zinc ion. It should be noted that the amines included in our study possess aminoethyl or aminomethyl moieties, in addition to aromatic/heterocyclic groups, which usually incorporate nitrogen atoms that can be protonated at $\mathrm{pH}$ values in the physiological range.

Data of Table 2 show that amines and amino acids of type 1-19 studied here act as effective or very effective CAAs against the bacterial enzyme SspCA. In fact only one compound, D-Phe $\mathbf{4}$ showed an activation constant $>1 \mu \mathrm{M}\left(K_{\mathrm{A}}\right.$ of $\left.5.13 \mu \mathrm{M}\right)$ whereas the remaining derivatives were highly effective CAAs of this enzyme, with activation constants in the range of $1 \mathrm{nM}-0.97 \mu \mathrm{M}$ (Table 2). The following structure-activity relationship (SAR) can be drawn from the data of Table 1 :

(i) All the amino acids investigated here as CAAs were highly effective activators, except for D-Phe, which, as mentioned above, was slightly less effective. As for other enzymes investigated earlier, ${ }^{14-20}$ the two enantiomers of the same amino acid showed highly different activity as CAAs, a situation also observed for the activation of SspCA. Thus, D-His was 9.2 times a better activator compared to L-His, whereas for phenylalanine, the reverse was true, with L-Phe being 641 times a better activator compared to D-Phe. It should be mentioned that this is the highest difference ever observed for the activation of a CA with two enantiomers of the same compound. Only for Trp the difference of activity 
Table 2

Activation constants of hCA I/hCA II (cytosolic isozymes), and SspCA with amino acids and amines 1-19. Data for hCA I and II activation with these compounds are from Ref. 19

\begin{tabular}{|c|c|c|c|c|}
\hline \multirow[t]{2}{*}{ No. } & \multirow[t]{2}{*}{ Compound } & \multicolumn{3}{|c|}{$K_{\mathrm{A}}^{\mathrm{a}}(\mu \mathrm{M})$} \\
\hline & & hCA I ${ }^{\mathrm{b}}$ & hCA II ${ }^{\mathrm{b}}$ & $\mathrm{SspCA}^{\mathrm{c}}$ \\
\hline 1 & L-His & 0.03 & 10.9 & 0.11 \\
\hline 2 & D-His & 0.09 & 43 & 0.012 \\
\hline 3 & L-Phe & 0.07 & 0.013 & 0.008 \\
\hline 4 & D-Phe & 86 & 0.035 & 5.13 \\
\hline 5 & L-DOPA & 3.1 & 11.4 & 0.09 \\
\hline 6 & D-DOPA & 4.9 & 7.8 & 0.43 \\
\hline 7 & L-Trp & 44 & 27 & 0.007 \\
\hline 8 & D-Trp & 41 & 12 & 0.002 \\
\hline 9 & L-Tyr & 0.02 & 0.011 & 0.001 \\
\hline 10 & D-Tyr & 0.34 & 0.087 & 0.83 \\
\hline 11 & 4- $\mathrm{H}_{2} \mathrm{~N}-\mathrm{L}-\mathrm{Phe}$ & 0.24 & 0.15 & 0.97 \\
\hline 12 & Histamine & 2.1 & 125 & 0.080 \\
\hline 13 & Dopamine & 13.5 & 9.2 & 0.037 \\
\hline 14 & Serotonin & 45 & 50 & 0.021 \\
\hline 15 & 2-Pyridyl-methylamine & 26 & 34 & 0.10 \\
\hline 16 & 2-(2-Aminoethyl)pyridine & 13 & 15 & 0.33 \\
\hline 17 & 1-(2-Aminoethyl)-piperazine & 7.4 & 2.3 & 0.09 \\
\hline 18 & 4-(2-Aminoethyl)-morpholine 0.14 & 0.14 & 0.19 & 0.10 \\
\hline 19 & L-Adrenaline & 0.09 & 96 & 0.68 \\
\hline
\end{tabular}

a Mean from three determinations by a stopped-flow, $\mathrm{CO}_{2}$ hydrase method. ${ }^{21}$ Standard errors were in the range of $5-10 \%$ of the reported values.

b Human recombinant isozymes, stopped flow $\mathrm{CO}_{2}$ hydrase assay method, data from Ref. 19.

c Bacterial recombinant enzyme, ${ }^{12}$ stopped flow $\mathrm{CO}_{2}$ hydrase assay method (this work).

between the two enantiomers is rather modest, both of them being quite effective SspCA activators $\left(K_{\mathrm{A}} \mathrm{S}\right.$ in the range of 2$7 \mathrm{nM})$. A highly effective activator was L-Tyr $\left(K_{\mathrm{A}}\right.$ of $\left.1 \mathrm{nM}\right)$ whereas its enantiomer was again less effective $\left(K_{\mathrm{A}}\right.$ of $0.83 \mu \mathrm{M})$.

(ii) The amines investigated as CAAs against SspCA were also effective but with a decreased efficacy compared to the amino acids discussed above. Thus, compounds 12-19 showed activation constants in the range of $21 \mathrm{nM}-$ $0.68 \mu \mathrm{M}$ (Table 2). Histamine 12, dopamine 13 and serotonin 14 were the best amine activators, with activation constants of 21-80 nM. Comparing these amines with the structurally related amino acids $1 / 2$ and $\mathbf{5 / 6}$ it may be observed that histamine 12 has an intermediate activity between L- and D-His, whereas dopamine $\mathbf{1 3}$ is more effective as a SspCA activator compared to both L- and D-DOPA. The heterocyclic amines incorporating aminomethyl or aminoethyl moieties 15-18 were also effective SspCA activators, with activation constants in the range of $0.09-0.33 \mu \mathrm{M}$ (Table 2). L-Adrenaline 19 was the least effective amine activator of the bacterial CA investigated here. It should be also noted that the activation profile of SspCA with compounds 1-19 is very different from that of the mammalian enzymes hCA I and II investigated earlier ${ }^{19}$ (Table 2). Particularly it should be noted that L-/D-Trp is very effective as an activator of the bacterial enzyme being a rather weak hCA I and II activator. Most of the amines investigated here were also more effective SspCA activators than hCA I and II activators.

Several research groups are developing various approaches for the stabilization of mammalian CA isoforms that enables the use of the enzyme for capturing carbon dioxide, but they have not been considered practical due to the low reaction rate and instability of the enzyme. ${ }^{22}$ The robustness of this enzyme makes SspCA proba- bly an interesting candidate for biotechnological applications in the field of $\mathrm{CO}_{2}$ fixation and we suggest that it might be possible to make SspCA an 'ideal molecule' in the $\mathrm{CO}_{2}$ sequestration achieving a high reaction rate through the use of CAAs. In the present paper we reported the effect of different CA activators on the SspCA activity. The CAA kinetic parameters obtained for the 'extremo- $\alpha$ CA' were compared with those of the mesophilic counterpart, demonstrating the special effect of these activators on this peculiar enzyme.

In conclusion, the first activation study of a bacterial CA is reported here. A series of amino acids and amines was included in the study. D-His, L-Phe, L-Tyr, L- and D-Trp were the most effective SspCA activators, with activation constants in the range of 1 $12 \mathrm{nM}$, whereas L-His, L/D-DOPA, D-Tyr, and several biogenic amines/catecholamines were slightly less effective activators $\left(K_{\mathrm{A}}\right.$ in the range of $37 \mathrm{nM}-0.97 \mu \mathrm{M})$. The least effective compound was D-Phe $\left(K_{\mathrm{A}}\right.$ of $\left.5.13 \mu \mathrm{M}\right)$. All these activators enhanced $k_{\text {cat }}$, having no effect on $K_{\mathrm{M}}$, favoring thus the rate determining step in the catalytic cycle, the proton transfer reactions between the active site and environment. The activation pattern of the bacterial enzyme SspCA is also very different when compared to those of the cytosolic, human isoforms hCA I and II. The thermal stability, robustness and very high catalytic activity of SspCA make it an ideal candidate for biomimetic $\mathrm{CO}_{2}$ capture processes.

\section{Acknowledgment}

This research was financed by an FP7 EU grant (Metoxia) and by a grant of the 'Accordo di Programma CNR-MSE'.

\section{References and notes}

1. Huessemann, M. H. Mar. Ecol. Progr. Series 2008, 364, 243.

2. Gentzis, T. Int. J. Coal Geol. 2000, 43, 287.

3. Greer, T.; Bedelbayev, A.; Igreja, J. M.; Gomes, J. F.; Lie, B. Environ. Technol. 2010, $31,107$.

4. Mignardi, S.; De Vito, C.; Ferrini, V.; Martin, R. F. J. Hazard. Mater. 2011, 191, 49.

5. Bond, G. M.; Stringer, J.; Brandvold, D. K.; Simsek, F. A.; Medina, M. G.; Egeland, G. Energy Fuels 2001, 15, 309.

6. (a) Pastorekova, S.; Parkkila, S.; Pastorek, J.; Supuran, C. T. J. Enzyme Inhib. Med Chem. 2004, 19, 199; (b) Scozzafava, A.; Mastrolorenzo, A.; Supuran, C. T. Expert Opin. Ther. Patents 2004, 14, 667; (c) Supuran, C. T.; Scozzafava, A.; Casini, A. Med. Res. Rev. 2003, 23, 146; (d) Scozzafava, A.; Mastrolorenzo, A.; Supuran, C. T. Expert Opin. Ther. Patents 2006, 16, 1627.

7. (a) Smith, K. S.; Jakubzick, C.; Whittam, T. S.; Ferry, J. G. Proc. Natl. Acad. Sci. U.S.A. 1999, 96, 15184; (b) Lehtonen, J.; Shen, B.; Vihinen, M.; Casini, A.; Scozzafava, A.; Supuran, C. T.; Parkkila, A. K.; Saarnio, J.; Kivela, A. J.; Waheed A.; Sly, W. S.; Parkkila, S. J. Biol. Chem. 2004, 279, 2719; (c) Alterio, V.; Di Fiore, A.; D’Ambrosio, K.; Supuran, C. T.; De Simone, G. Chem. Rev. 2012, 112, 4421.

8. (a) Supuran, C. T. Nat. Rev. Drug Disc. 2008, 7, 168; (b) Supuran, C. T. Bioorg. Med. Chem. Lett. 2010, 20, 3467; (c) Supuran, C. T. Curr. Pharm. Des. 2010, 16, 3233. (d) Neri, D.; Supuran, C. T. Nat. Rev. Drug Disc. 2011, 10, 767.

9. (a) Xu, Y.; Feng, L.; Jeffrey, P. D.; Shi, Y.; Morel, F. M. Nature 2008, 452, 56; (b) Viparelli, F.; Monti, S. M.; De Simone, G.; Innocenti, A.; Scozzafava, A.; Xu, Y.; Morel, F. M. M.; Supuran, C. T. Bioorg. Med. Chem. Lett. 2010, 20, 4745; (c) Alterio, V.; Langella, E.; Viparelli, F.; Vullo, D.; Ascione, G.; Dathan, N. A.; Morel, F. M. M.; Supuran, C. T.; De Simone, G.; Monti, S. M. Biochimie 2012, 94, 1232.

10. (a) Domsic, J. F.; Avvaru, B. S.; Kim, C. U.; Gruner, S. M.; Agbandje-McKenna, M.; Silverman, D. N.; McKenna, R. J. Biol. Chem. 2008, 283, 30766; (b) Clare, B. W.; Supuran, C. T. Eur. J. Med. Chem. 1999, 34, 463; (c) Supuran, C. T.; Scozzafava, A. J. Enzyme Inhib. 1997, 12, 37.

11. (a) Supuran, C. T. Front. Pharmacol. 2011, 2, 34; (b) Schlicker, C.; Hall, R. A. Vullo, D.; Middelhaufe, S.; Gertz, M.; Supuran, C. T.; Mühlschlegel, F. A. Steegborn, C. J. Mol. Biol. 2009, 385, 1207; (c) Zimmerman, S. A.; Ferry, J. G.; Supuran, C. T. Curr. Top. Med. Chem. 2007, 7, 901; (d) Burghout, P.; Vullo, D.; Scozzafava, A.; Hermans, P. W. M.; Supuran, C. T. Bioorg. Med. Chem. 2011, 19, 243.

12. Capasso, C.; De Luca, V.; Carginale, V.; Rossi, M. J. Enzyme Inhib. Med. Chem. 27 in press. http://dx.doi:10.3109/14756366.2012.703185. Competent E. coli BL21 (DE3) cells were transformed with the plasmid pET15b containing the Sulfurihydrogenibium sp. gene encoding for the CA and lacking the signal peptide (first 20 amino acid of the peptide sequence). Cells were grown at $37^{\circ} \mathrm{C}$ and induced with $1 \mathrm{mM}$ IPTG. After additional growth for $5 \mathrm{~h}$, the cells were harvested and disrupted by sonication at $4{ }^{\circ} \mathrm{C}$. Following centrifugation, the cell extract was heated at $90{ }^{\circ} \mathrm{C}$ for $30 \mathrm{~min}$ and centrifuged. The supernatant 
was loaded into His-select HF Nickel affinity gel and the protein was eluted with $250 \mathrm{mM}$ imidazole. At this stage of purification the enzyme was at least $95 \%$ pure.

13. (a) De Luca, V.; Vullo, D.; Scozzafava, A.; Carginale, V.; Rossi, M.; Supuran, C. T.; Capasso, C. Bioorg. Med. Chem. Lett. 2012, 22, 5630; (b) Vullo, D.; De Luca, V. Scozzafava, A.; Carginale, V.; Rossi, M.; Supuran, C.T.; Capasso, C. Bioorg. Med. Chem. in press. http://dx.doi.org/10.1016/j.bmc.2012.07.024.

14. (a) Supuran, C. T.; Scozzafava, A. Activation of carbonic anhydrase isozymes. In The Carbonic Anhydrases-New Horizons; Chegwidden, W. R., Carter, N., Edwards, Y., Eds.; Birkhauser Verlag: Basel, Switzerland, 2000; pp 197-219; (b) Ilies, M.; Scozzafava, A.; Supuran, C. T. Carbonic anhydrase activators. In Carbonic Anhydrase-Its Inhibitors and Activators; Supuran, C. T., Scozzafava, A., Conway, J., Eds.; CRC Press: Boca Raton (FL), USA, 2004; pp 317-352.

15. (a) Briganti, F.; Mangani, S.; Orioli, P.; Scozzafava, A.; Vernaglione, G.; Supuran C. T. Biochemistry 1997, 36, 10384; (b) Temperini, C.; Scozzafava, A.; Puccetti L.; Supuran, C. T. Bioorg. Med. Chem. Lett. 2005, 15, 5136.

16. Sun, M. K.; Alkon, D. L. J. Pharmacol. Exp. Ther. 2001, 297, 961.

17. (a) Temperini, C.; Scozzafava, A.; Vullo, D.; Supuran, C. T. Chemistry 2006, 12 , 7057; (b) Temperini, C.; Scozzafava, A.; Vullo, D.; Supuran, C. T. J. Med. Chem 2006, 49, 3019.

18. (a) Temperini, C.; Scozzafava, A.; Supuran, C. T. Bioorg. Med. Chem. Lett. 2006, 16, 5152; (b) Temperini, C.; Innocenti, A.; Scozzafava, A.; Mastrolorenzo, A.; Supuran, C. T. Bioorg. Med. Chem. Lett. 2007, 17, 628; (c) Parkkila, S.; Vullo, D.; Puccetti, L.; Parkkila, A. K.; Scozzafava, A.; Supuran, C. T. Bioorg. Med. Chem. Lett. 2006, 16, 3955.

19. (a) Temperini, C.; Innocenti, A.; Scozzafava, A.; Supuran, C. T. Bioorg. Med. Chem. 2008, 16, 8373; (b) Temperini, C.; Scozzafava, A.; Supuran, C. T. Curr. Pharm. Des. 2008, 14, 708 .

20. (a) Innocenti, A.; Leewattanapasuk, W.; Manole, G.; Scozzafava, A.; Mühlschlegel, F. A.; Supuran, C. T. Bioorg. Med. Chem. Lett. 2010, 20, 1701; (b) Innocenti, A.; Hall, R. A.; Scozzafava, A.; Mühlschlegel, F. A.; Supuran, C. T. Bioorg. Med. Chem. 2010, 18, 1034.

21. Khalifah, R.G. J. Biol. Chem. 1971, 246, 2561. An Applied Photophysics stoppedflow instrument has been used for assaying the $\mathrm{CA}$ catalysed $\mathrm{CO}_{2}$ hydration activity. Phenol red (at a concentration of $0.2 \mathrm{mM}$ ) has been used as indicator, working at the absorbance maximum of $557 \mathrm{~nm}$, with $10 \mathrm{mM}$ Hepes $(\mathrm{pH} 7.5)$ as buffer, $0.1 \mathrm{M} \mathrm{Na}_{2} \mathrm{SO}_{4}$ (for maintaining constant the ionic strength), following the CA-catalyzed $\mathrm{CO}_{2}$ hydration reaction for a period of $10 \mathrm{~s}$. The $\mathrm{CO}_{2}$ concentrations ranged from 1.7 to $17 \mathrm{mM}$ for the determination of the kinetic parameters and activation constants. For each activator at least six traces of the initial $5-10 \%$ of the reaction have been used for determining the initial velocity. The uncatalyzed rates were determined in the same manner and subtracted from the total observed rates. Stock solutions of activators 1-17 $(10 \mathrm{mM})$ were prepared in distilled-deionized water and dilutions up to $0.001 \mu \mathrm{M}$ were done thereafter with the assay buffer. Activator and enzyme solutions were preincubated together for $15 \mathrm{~min}$ at room temperature prior to assay, in order to allow for the formation of the E-A complex. The activation constant $\left(K_{\mathrm{A}}\right)$, defined similarly with the inhibition constant $K_{\mathrm{I}}{ }^{15,17}$ may be obtained by considering the classical Michaelis-Menten equation (Eq. 1), which has been fitted by non-linear least squares by using PRISM 3:

$v=v_{\max } /\left\{1+K_{\mathrm{M}} /[\mathrm{S}]\left(1+[A]_{\mathrm{f}} / K_{\mathrm{A}}\right)\right\}$

where $[A]_{\mathrm{f}}$ is the free concentration of activator.

Working at substrate concentrations considerably lower than $K_{\mathrm{M}}\left([\mathrm{S}] \ll K_{\mathrm{M}}\right)$, and considering that $[A]_{\mathrm{f}}$ can be represented in the form of the total concentration of the enzyme $\left([E]_{\mathrm{t}}\right)$ and activator $\left([A]_{\mathrm{t}}\right)$, the obtained competitive steadystate equation for determining the activation constant is given by Eq. $2:{ }^{17}$

$$
\begin{aligned}
v= & v_{0} \cdot K_{\mathrm{A}} /\left\{K_{\mathrm{A}}+\left([A]_{\mathrm{t}}-0.5\left\{\left([A]_{\mathrm{t}}+[E]_{\mathrm{t}}+K_{\mathrm{A}}\right)-\left([A]_{\mathrm{t}}+[E]_{\mathrm{t}}\right.\right.\right.\right. \\
& \left.\left.\left.\left.+K_{\mathrm{A}}\right)^{2}-4[A]_{\mathrm{t}} \cdot[E] \mathrm{t}\right)^{1 / 2}\right\}\right\}
\end{aligned}
$$

where $v_{0}$ represents the initial velocity of the enzyme-catalyzed reaction in the absence of activator. ${ }^{17}$

22. Fisher, Z.; Boone, C. D.; Biswas, S. M.; Venkatakrishnan, B.; Aggarwal, M.; Tu, C.; Agbandje-McKenna, M.; Silverman, D.; McKenna, R. Protein Eng. Des. Sel. 2012, 25,347 . 